\title{
Finance Results of Organizations Activity Analysis and Ways of Increase
}

\author{
Khramchenko A.A. \\ Finance Department \\ I.T. Turbilin Kuban State Budgetary Agrarian University \\ Krasnodar, Russia \\ an.hramchenko@yandex.ru
}

\author{
Bolotnova E.A. \\ Economic Analysis Department \\ I.T. Turbilin Kuban State Budgetary Agrarian University \\ Krasnodar, Russia \\ an.hramchenko@yandex.ru
}

\begin{abstract}
Finance result is the main evaluation criterion of finance-economic activity of organization and is reflected in income or loss. Owing to finance results analysis people form the opinion about profitability of a subject. Finance results analysis in general is calculated taking into account the structure of a product. In terms of finance results analysis, the factors influence on the effectiveness index at each stage of the mentioned above methodology is estimated. Determined factorial analysis is the methodology of factors influence estimation, the connection of which with the effectiveness index has a functional character. It means that the effectiveness index can be presented in a form of a product, partial or algebraic sum of factors.
\end{abstract}

Keywords-finance result; market monitoring; project payback; enterprise analysis; $A B C$-analysis.

\section{INTRODUCTION}

Market analysis showed that in closed joint-stock company experimental- industrial economy "Central" ("Tsentralnoe") apples storage till December-January is insufficient for an optimal selling price getting, which helps economy to realize widened reproduction and direct the means toward social guarantees of workers strengthening. In accordance with this it is recommended to create the storage with the duration of products realization in February-March-April.

Taking into account the volumes of apples realization in closed joint-stock company experimental- industrial economy "Central" ("Tsentralnoe") during the period 2016-2018, the average volume of realization is 6277 tons. At the same time, as the research works show almost 3077 tons of products closed joint-stock company experimental- industrial economy "Central" ("Tsentralnoe") can provide right according state order for sale, preservation and processing. The rest 3200 tons is necessary to send into the storage for a long time period with further realization with more advantageous price.

Let's consider technical task of the project (table I).

It is necessary to place 16 rooms of controlled atmosphere in the storage for 200 tons of apples. The storage rooms with the controlled atmosphere nowadays are very expensive, however, this technological solution helps to preserve marketable state of the product during a long time period.
TABLE I. INPUT DATA OF FRUIT STORAGE CREATION PROJECT (FOR 3200 TONS)

\begin{tabular}{|c|c|c|c|}
\hline № & Item & \multicolumn{2}{|c|}{ Value } \\
\hline 1 & Place of building & \multicolumn{2}{|c|}{ Krasnodar region } \\
\hline 2 & The aim of the building & \multicolumn{2}{|c|}{ Fruit storage } \\
\hline 3 & Product description & \multicolumn{2}{|c|}{ apples } \\
\hline 4 & Number of cameras, items & 15 & 1 \\
\hline 5 & Technological regime & $\begin{array}{l}\text { controlled } \\
\text { atmosphere }\end{array}$ & $\begin{array}{l}\text { Preliminar } \\
\text { y cooling / } \\
\text { storage in } \\
\text { controlled } \\
\text { atmosphere }\end{array}$ \\
\hline 6 & $\begin{array}{l}\text { Oriented cameras sizes } \\
(\mathrm{LxW} \times \mathrm{H}), \mathrm{m}\end{array}$ & $14 \times 8 \times 8$ & $14 \times 8 \times 8$ \\
\hline 7 & $\begin{array}{l}\text { The temperature of the } \\
\text { product, which is put into the } \\
\text { room, }{ }^{\circ} \mathrm{C}\end{array}$ & \multicolumn{2}{|c|}{+25} \\
\hline 8 & $\begin{array}{l}\text { Daily product provision into } \\
\text { the storage, tons }\end{array}$ & \multicolumn{2}{|c|}{105} \\
\hline
\end{tabular}

The average crop productivity of products marketable state of intensive type orchards is 35 tons/ha. Everyday crop gathering from 3 ha of the land provides products into fruit storage for preliminary cooling with the volume of 105 tons, among which $30 \%$ of the volume take apples of $60+$ caliber and $70 \%$-the apples of $40+$ caliber. These 105 tons are put into the rooms of the storage with the volume $20 \%$, so it is possible to fill 5 rooms within one day. Table 2 presents the list of necessary materials and equipment for cooling chamber operation in order to preserve 3200 tons of apples.

Market monitoring helped to set the price of necessary for closed joint-stock company experimental- industrial economy "Central" ("Tsentralnoe") materials and equipment for fruit storage operation.

For 16 storage rooms filling it is necessary to buy 12000 wooden containers - 750 into one room, taking into account walkways between the containers and gaps for air circulation.

The line of milling is necessary for products sorting, calibration and washing, which then goes to storage rooms. As heat-insulating part of the storages we offer to use sandwich panel with polyurethane foam, which will help to decrease 
heat conduction and the weight of panels, increase strength characteristics and decrease till zero index the possibility of burning support. This kind of panels is water and aggressive substances resistant.

TABLE II. NECESSARY MATERIALS AND EQUIPMENT FOR REFRIGERATOR OPERATION FOR 3200 TONS OF PRODUCTS

\begin{tabular}{|c|l|c|}
\hline № & \multicolumn{1}{|c|}{ Item } & $\begin{array}{c}\text { Price, } \\
\text { thousands } \\
\text { of rubles }\end{array}$ \\
\hline 1 & $\begin{array}{l}\text { Wooden containers }(1,2 \times 1,0 \text { x 0,8) m 12000 items. x } \\
1500 \text { rubles }\end{array}$ & 18000 \\
\hline 2 & Line of milling & 27000 \\
\hline 3 & Field for loading and unloading works & 1000 \\
\hline 4 & $\begin{array}{l}\text { Electric elevators (Toyota, block tyre, lift 6,5 m, load- } \\
\text { carrying 1,5 tons) 4 units 2500 thousands of rubles each }\end{array}$ & 10000 \\
\hline 5 & $\begin{array}{l}\text { Car lift (gas, gasoline, pneumoniae H 4 m, carrying } \\
\text { capacity 1,5 m) 2 units 1500 rubles each }\end{array}$ & 3000 \\
\hline 6 & A car delivery truck & 7000 \\
\hline 7 & Diesel power plant for 300 kilowatts & 3000 \\
\hline 8 & Electric power 400 kilowatt x 13000 rubles & 5200 \\
\hline 9 & branch office & 1000 \\
\hline 1 & Laying asphalt road with communications & 4500 \\
\hline 1 & Weight station building for 60 tons & 3000 \\
\hline 1 & Costs, connected with compartments filling & 1800 \\
\hline 2 & Total & 84500 \\
\hline
\end{tabular}

In order to realize the technology of storage in controlled atmosphere (CA) it is recommended to put the complex of the following equipment:

1. Nitrogen atmosphere generator VSA 30 - used for oxygen concentration decrease in rooms till the set level and gas regime renewal in case of rooms opening and products unload. It is based on ecologically clean air division into nitrogen and oxygen;

2. Adsorber CO2 ST 950 - used for carbon dioxide removal from the rooms and its preservation at a necessary level.

Refrigerator sets market monitoring helped to define some companies, whose offers concerning fruit storage creation are the most advantageous: LLC "Infrost", LLC "Agro-stroitelnye tekhnologii" and LLC "VolgaStroy". On the basis of the data, offered by the companies, we calculated the average prices concerning storage rooms creation. Thus, storage building, including general building works will cost 64000 rubles, refrigeration supply unit equipment -32000 rubles, regulated atmosphere unit equipment-19000 rubles.

Total cost of the project, offered in order to increase finance results of closed joint-stock company experimentalindustrial economy "Central" ("Tsentralnoe") will be 199500 rubles.

Reasonable solutions of the project include the costs on the storage building with the units of refrigeration supply and regulated gas environment (table III).
TABLE III. MATERIALS AND EQUIPMENT FOR FRUIT STORAGE BUILDING FOR 3200 TONS

\begin{tabular}{|c|c|c|c|}
\hline № & \multicolumn{1}{|c|}{ Item } & $\begin{array}{c}\text { Unit of } \\
\text { measure }\end{array}$ & $\begin{array}{c}\text { Num } \\
\text { ber }\end{array}$ \\
\hline 1 & 2 & 3 & 4 \\
\hline \multicolumn{3}{|c|}{ Storage building } \\
\hline 1 & $\begin{array}{c}\text { Sandwich panels (polyurethane foam } \\
\text { ceiling of milling room) }\end{array}$ & set & 1 \\
\hline 2 & $\begin{array}{l}\text { Fastening profiles, pressurizing } \\
\text { facilities, installation and expendable } \\
\text { materials }\end{array}$ & set & 1 \\
\hline 3 & Sliding door 2,4 x 3,0 m sealed for CA & items & 16 \\
\hline 4 & Sectional gate 3x3 & items & 1 \\
\hline 5 & Heated swing door $1,0 \times 2,0 \mathrm{~m}$ & items & 3 \\
\hline 6 & Lighting installation & set & 1 \\
\hline 7 & Installation of panels and doors & service & 1 \\
\hline
\end{tabular}

The market of agricultural producers analysis showed that in the average funding during recent 3-4 years was 30\%. The rest of the sum $-70 \%$, necessary for the project realization, should be taken as an investment credit in VTB (outer merchant bank) of $14,7 \%$ per annum for property and building purchase.

\section{RESULTS}

In order to fulfill necessary calculation of project payback it is necessary to do the following:

1. To define the period, during which the invested means should start to provide income. Nowadays long-term investments into the project are done only if the period of payback takes no more than 5-6 years;

2. To calculate additional income into closed joint-stock company experimental- industrial economy "Central" ("Tsentralnoe") from apples realization during the period since February till April. The average price of apples during this period of the year is the following: $60+$ caliber -50 rubles for $1 \mathrm{~kg}, 40+$ caliber -35 rubles for $1 \mathrm{~kg}$. General volume of a cash flow form apples sell every year will be 126400 rubles;

3. To define the volume of outlays on the storage running, taking into account the results of statistics and refrigerating units market monitoring (table 4). General volume of outlays from apples sell (3200 tons) will annually be 60898 rubles.

4. Payback analysis helped to come to the following conclusion: the project of fruit storage creation on the basis of closed joint-stock company experimental- industrial economy "Central" ("Tsentralnoe") will pay its way during 4,3 years, taking into account all costs, which will help the organization to get income from building, starting from the $5^{\text {th }}$ year of apples storage exploitation. 
TABLE IV. ANNUAL OUTLAYS ON STORAGE OPERATION WITH CALCULATED PER 1 KG OF PRODUCTION OF CLOSED JOINTSTOCK COMPANY EXPERIMENTAL- INDUSTRIAL ECONOMY "CENTRAL" ("TSENTRALNOE")

\begin{tabular}{|l|c|}
\hline Cost items & $\begin{array}{c}\text { Costs calculated per 1 kg of } \\
\text { storage, rubles }\end{array}$ \\
\hline Wages with payments & 5,45 \\
\hline Outlays on administrative costs & 0,375 \\
\hline $\begin{array}{l}\text { Permanent and thorough repair of } \\
\text { buildings }\end{array}$ & 0,26 \\
\hline $\begin{array}{l}\text { Permanent and thorough repair of } \\
\text { equipment }\end{array}$ & 0,65 \\
\hline $\begin{array}{l}\text { Cleaning, laboratory, Private Security } \\
\text { Agency (PSA) }\end{array}$ & 0,19 \\
\hline Loaders work & 0,12 \\
\hline Materials & 7,66 \\
\hline Containers and container materials & 0,34 \\
\hline Autoservices & 0,008 \\
\hline Community charges & 1,25 \\
\hline $\begin{array}{l}\text { Occupational safety, life safety (LS), safety } \\
\text { technique (ST) }\end{array}$ & 0,16 \\
\hline Power supply & 1,63 \\
\hline Fuels and lubricants oils (FLO) & 0,9375 \\
\hline Total costs & 19,0305 \\
\hline
\end{tabular}

The period of payback calculation is reasonable to present in table V.

TABLE V. THE PERIOD OF FRUIT STORAGE (FOR 3200 TONS) PAYBACK CALCULATION

\begin{tabular}{|c|c|c|c|}
\hline Period & $\begin{array}{c}\text { Cash flow, } \\
\text { rubles }\end{array}$ & $\begin{array}{c}\text { Discounted cash } \\
\text { flow, rubles }\end{array}$ & $\begin{array}{c}\text { Accumulated } \\
\text { discounted cash } \\
\text { flow, rubles }\end{array}$ \\
\hline 0 & -199500000 & $-199500000,00$ & $-199500000,00$ \\
\hline 1 & 65502400 & 57107585,00 & $-142392415,00$ \\
\hline 2 & 65502400 & 49788653,01 & $-92603761,98$ \\
\hline 3 & 65502400 & 43407718,41 & $-49196043,58$ \\
\hline 4 & 65502400 & 37844567,05 & $-11351476,53$ \\
\hline 5 & 65502400 & 32994391,50 & 21642914,97 \\
\hline 6 & 65502400 & 28765816,48 & 50408731,45 \\
\hline
\end{tabular}

Fruit storage for 3200 tons bringing into service would help closed joint-stock company experimental- industrial economy "Central" ("Tsentralnoe") to increase effectiveness indices of activity and profitability. Possible effect from the project realization in terms of price indices and costing preservation in 2018 is presented in table VI.
TABLE VI. THE EFFECTIVENESS OF FRUIT STORAGE CREATION PROJECT FOR 3200 TONS OF APPLES FOR CLOSED JOINT-STOCK COMPANY EXPERIMENTAL- INDUSTRIAL ECONOMY "CENTRAL" (“TSENTRALNOE")

\begin{tabular}{|c|c|c|c|}
\hline \multicolumn{1}{|c|}{ Index } & 2018 & $\begin{array}{c}\text { Planned } \\
\text { indices }\end{array}$ & $\begin{array}{c}\text { Planned } \\
\text { indices } \\
\text { change }(+/-) \\
\text { by } 2018\end{array}$ \\
\hline Volume & 59350 & 62770 & 3420 \\
\hline $\begin{array}{c}\text { Earnings, thousand rubles } \\
\text { Cost of sales, thousand rubles }\end{array}$ & $\begin{array}{c}16420 \\
\text { Commercial, administrative }\end{array}$ & 180432 & 76232 \\
\hline $\begin{array}{c}\text { costs and outlays on storage } \\
\text { operation, thousand rubles }\end{array}$ & $\mathrm{x}$ & 60898 & 9430 \\
\hline $\begin{array}{c}\text { Income (loss) from sales, } \\
\text { thousand rubles }\end{array}$ & -59678 & 7124 & 66802 \\
\hline $\begin{array}{c}\text { Norm of profitability (loss } \\
\text { ratio) }\end{array}$ & $-0,364$ & 0,041 & 0,405 \\
\hline $\begin{array}{l}\text { Sources of funds, thousand rubles }- \text { total } \\
\text { including own means, thousand rubles }\end{array}$ & 199500 & $\mathrm{x}$ \\
\hline $\begin{array}{l}\text { loans, thousand rubles } \\
\text { Rate on credit, \% }\end{array}$ & 59850 & $\mathrm{x}$ \\
\hline $\begin{array}{l}\text { Additional income, thousand rubles } \\
\text { Period of project payback, years }\end{array}$ & 139650 & $\mathrm{x}$ \\
\hline
\end{tabular}

\section{CONCLUSION}

On the basis of the held analysis of finance results of closed joint-stock company experimental- industrial economy "Central" ("Tsentralnoe") the following means of their improvement are offered:

In terms of product structure optimization on the basis of finance results $\mathrm{ABC}$ and $\mathrm{XYZ}$-analysis we had the following results:

1) Wheat is one of the most stable kind of production in the organization, which helps to stress other groups of production during further events creation;

2) Sunflower seeds, which are considered less useful group of product from the point of view of its selling effectiveness, are not the main kind of product in closed jointstock company experimental- industrial economy "Central" ("Tsentralnoe"), but it gives stable income to the organization;

3) In accordance with the results of compound analysis of strawberry production in closed joint-stock company experimental- industrial economy "Central" ("Tsentralnoe") it is recommended to sign a contracts for berries supply into the organization of mass foodservice, such as kindergartens and sanatorium on the basis of state order;

4) Speaking about pomaceous fruits -apples, it is reasonable to make the project of storage creation for a longterm storage with cooling and calculate possible period of project payback and its profitability for the organization. 
[5] Ozhegova A.V. Effectiveness of means use and the ways of its increase. In the collection of works: Innovations and science: Collection of articles of the International scientific-practical conference: in 4 parts. 2018, 320.

\section{References}

[1] Abdukarimov I.T. Finance-economic analysis of economic activity among commerce organizations (business activity analysis): manual. Moscow: SRC INFRA-M. 2017, 320.

[2] Baskakova O. V., Seyko L. F. Enterprise economics (organization): textbook. Moscow: Dashkov and $\mathrm{K}^{\circ} .2017,372$.

[3] Kovryakova E.A. About the situation in rice-growing and the prospects of this sphere steady development. Scientific education. 2014, 8-2, pp. 681683

[4] Melnik M.V., Gerasimova E.B. Finance-economic activity of enterprise analysis: manual- the $3^{\text {rd }}$ edition, transferred and added- Moscow : Publishing house «FORUM» : INFRA-M. 2018, 208.

[6] Omarov R.S. Modern technological solutions in the production of restructured ham. Research Journal of Pharmaceutical, Biological and Chemical Sciences. 2019, vol. 10, 2, pp. 1045-1051.

[7] Pozdnyakova V.Ya. Finance-economic activity of enterprises analysis and diagnostics: Textbook. Moscow.: SRC INFRA-M. 2017, 617.

[8] Alexsandr S. Kuznetsov. Russian Professor's meeting. Russian Journal of Physical Education and Sport. 2019, 14(1), pp. 17-22. DOI: 10.14526/2070-4798-2019-14-1-18-24

[9] Khramcheko A.A. The question of working capital stockturn and financial state improvement in general by the example of dairy farm of Krasnodar region. Economics and business. 2016, 12-3(77), pp. 561-567. 